\section{OPEN ACCESS}

Edited by:

Jiri Kanta,

Charles University Faculty of Medicine Hradec Kralove, Czech Republic

Reviewed by:

Elke Roeb,

Justus-Liebig-University Giessen

Germany

Wing-Kin Syn

Foundation for Liver Research, UK

*Correspondence:

Tatiana Kisseleva

tkisseleva@ucsd.edu;

David A. Brenner

dbrenner@ucsd.edu

Specialty section:

This article was submitted to

Gastrointestinal Sciences,

a section of the journal

Frontiers in Physiology

Received: 13 August 2015 Accepted: 01 February 2016

Published: 16 February 2016

Citation:

Wang P, Koyama Y, LiU X, XU J,

Ma H-Y, Liang S, Kim IH, Brenner DA and Kisseleva T (2016) Promising

Therapy Candidates for Liver Fibrosis.

Front. Physiol. 7:47.

doi: 10.3389/fphys.2016.00047

\title{
Promising Therapy Candidates for Liver Fibrosis
}

\author{
Ping Wang 1,2,3, Yukinori Koyama ${ }^{1,2,4}$, Xiao Liu ${ }^{1,2}$, Jun $\mathrm{Xu}^{1,2}$, Hsiao-Yen Ma ${ }^{1,2}$, \\ Shuang Liang ${ }^{1,2}$, In H. Kim ${ }^{1,2}$, David A. Brenner ${ }^{2 *}$ and Tatiana Kisseleva ${ }^{1 *}$ \\ ${ }^{1}$ Department of Surgery, University of California, San Diego, La Jolla, CA, USA, ${ }^{2}$ Department of Medicine, University of \\ California, San Diego, La Jolla, CA, USA, ${ }^{3}$ Liver Research Center, Beijing Friendship Hospital, Capital Medical University, \\ Beijing, China, ${ }^{4}$ Department of Surgery, Graduate School of Medicine, Kyoto University, Kyoto, Japan
}

Liver fibrosis is a wound-healing process in response to repeated and chronic injury to hepatocytes and/or cholangiocytes. Ongoing hepatocyte apoptosis or necrosis lead to increase in ROS production and decrease in antioxidant activity, which recruits inflammatory cells from the blood and activate hepatic stellate cells (HSCs) changing to myofibroblasts. Injury to cholangiocytes also recruits inflammatory cells to the liver and activates portal fibroblasts in the portal area, which release molecules to activate and amplify cholangiocytes. No matter what origin of myofibroblasts, either HSCs or portal fibroblasts, they share similar characteristics, including being positive for $\alpha$-smooth muscle actin and producing extracellular matrix. Based on the extensive pathogenesis knowledge of liver fibrosis, therapeutic strategies have been designed to target each step of this process, including hepatocyte apoptosis, cholangiocyte proliferation, inflammation, and activation of myofibroblasts to deposit extracellular matrix, yet the current therapies are still in early-phase clinical development. There is an urgent need to translate the molecular mechanism of liver fibrosis to effective and potent reagents or therapies in human.

Keywords: liver fibrosis, hepatocytes, cholangiocyte, inflammation, myofibroblasts, early-phase clinical trial

\section{INTRODUCTION}

Liver fibrosis is a wound-healing process of the liver in response to repeated and chronic liver injury with distinct etiologies, such as infectious diseases (e.g., viral hepatitis), metabolic derangements (non-alcoholic steatohepatitis), exposure to chemicals (e.g., alcohol liver diseases), or autoimmune diseases (e.g., primary biliary cirrhosis, primary sclerosing cholangitis, and autoimmune hepatitis). The identical morphology characteristics of liver fibrosis are the quantitative and qualitative deposition of extracellular matrix which is produced by myofibroblasts. Myofibroblasts are absent from the healthy liver, accumulate in the injured liver and serve as the principle effector cells of fibrogenesis. Although control and clearance of the underlying causative etiology (e.g., virus eradication or alcohol absence) can slow down fibrosis progression and lead to fibrosis regression, the extensive knowledge on the mechanism leading to liver fibrosis through hepatocyte injury, chaolangiocyte proliferation, inflammation, and activation of myofibroblasts to deposit extracellular matrix has not been translated into effective and potent reagents or therapies in human so far (Hauff et al., 2015). In this review we would like to summarize the current knowledge of targeting each step of the pathologenesis process to relieve liver fibrosis. 


\section{INJURY-INDUCED HEPATOCYTE APOPTOSIS}

Chronic liver injury, including viral hepatitis and nonalcoholic steatohepatitis (NASH), is typically associated with apoptosis of hepatocytes, which recruit inflammatory cells and promote liver fibrosis. Inactivation of Caspase 1, Caspase 2, or Caspase 3 protects hepatocytes against apoptosis, reduces cytokines involved in inflammatory signaling, and ameliorates fibrogenesis in diet-induced NASH models (Dixon et al., 2012; Machado et al., 2014; Thapaliya et al., 2014). The pan-caspase inhibitor, VX-166 could reduce oxidative stress, inflammation, HSC activation, and extracellular matrix deposition in non-alcoholic steatohepatis mouse (Witek et al., 2009; Anstee et al., 2010). Another pan-caspase inhibitor, IDN-6556, also attenuates hepatic inflammation, hepatic stellate cells (HSCs) activation, and liver fibrosis in murine bile duct ligation (BDL) model (Canbay et al., 2004) and steatohepatitis models (Barreyro et al., 2015). In a clinical study, oral administration of IDN-6556 can reduce aminotransferase activity in chronic hepatitis $\mathrm{C}$ patients (Pockros et al., 2007). Now, IDN-6556 has been completed the investigation in randomized, double-blind phase II studies for the treatment of Non-alcoholic fatty liver disease (NAFLD), hepatitis $\mathrm{C}$ virus (HCV), and cirrhosis (Table 1). Interestingly, co-administration of an antioxidant (lithospermate B) and caspase inhibitor (nivocasan) can suppress oxidative stress and hepatocyte apoptosis, resulting in a combined effect on reversal of liver fibrosis in rats (Kim do et al., 2013), which provides a better basis for effective therapy to liver fibrosis.

\section{INJURY-INDUCED CHOLANGIOCYTE PROLIFERATION}

Injury to cholangiocytes recruits inflammatory cells from the blood and activates portal fibroblasts in the portal area, which release molecules to activate and amplify the proliferation biliary progenitor cells (activated cholangiocytes). In BDL cholestatic injury model, bile ductular cells and fibroblasticappearing cells in the portal area express Hedgehog (Hh) ligands, receptor, and/or target genes (Omenetti et al., 2007). Furthermore, myofibroblasts release soluble Hh ligands that stimulate cholangiocytes to produce Cxcl16 and recruit NKT cells (Omenetti et al., 2009). Hh signaling antagonist GDC-0449 could inhibit liver myofibroblasts and progenitors, relieve liver fibrosis, and even promotes regression of HCC in phospholipid flippase (Mdr2) knockout mice (Philips et al., 2011). Integrin $\alpha v \beta 6$, which is another molecular absent in normal liver, promotes proliferation of cholangiocytes and plays functional roles in activating latent TGF- $\beta 1$. Cholangiocytes exhibit marked increased expression of $\alpha \mathrm{v} \beta 6$ integrin in thioacetamide (TAA)and BDL-induced fibrosis, and in human HCV fibrosis and end-stage cirrhosis (Wang et al., 2007; Popov et al., 2008). Inhibition of $\alpha v \beta 6$ could attenuate collagen deposition, improve liver function, and retard progression of biliary fibrosis in mouse orthotopic liver transplantation model (Chen et al., 2013). Impressively, a single dose of integrin $\alpha v \beta 6$ inhibitor exhibits
TABLE 1 | Liver injury animal model findings with potential antifibrotic effects.

\begin{tabular}{|c|c|c|c|}
\hline Targets & Mechanism & Intervention & Animal model \\
\hline \multirow[t]{2}{*}{$\begin{array}{l}\text { Injured } \\
\text { hepatocytes }\end{array}$} & $\begin{array}{l}\text { Pan-caspase } \\
\text { inhibitor }\end{array}$ & $V X-166$ & NAFLD \\
\hline & $\begin{array}{l}\text { Pan-caspase } \\
\text { inhibitor }\end{array}$ & IDN-6556 & BDL; NAFLD \\
\hline Cholangiocyte & $\begin{array}{l}\text { Hh signaling } \\
\text { antagonist }\end{array}$ & GDC-0449 & Mdr2-/- \\
\hline \multirow[t]{2}{*}{ Proliferation } & $\begin{array}{l}\text { Integrin } \alpha \mathrm{v} \beta 6 \\
\text { antagonist }\end{array}$ & Integrin $\alpha v \beta 6$ antibody & $\begin{array}{l}\text { Ischemia-related } \\
\text { biliary fibrosis after } \\
\text { orthotopic liver } \\
\text { transplantation }\end{array}$ \\
\hline & $\begin{array}{l}\text { Integrin } \alpha \vee \beta 6 \\
\text { antagonist }\end{array}$ & EMD527040 & Mdr2-/- \\
\hline $\begin{array}{l}\text { Recruitment } \\
\text { of }\end{array}$ & $\begin{array}{l}\text { P2X7 } \\
\text { antagonist }\end{array}$ & A438079 & $\begin{array}{l}\text { CCl4; } \\
\text { acetaminophen }\end{array}$ \\
\hline \multirow{4}{*}{$\begin{array}{l}\text { inflammatory } \\
\text { cells }\end{array}$} & CXCR2-FPR1 & BOC-1 and DF2156a & acetaminophen \\
\hline & $\begin{array}{l}\text { HMGB1- } \\
\text { mediated } \\
\text { inflammatory } \\
\text { signaling }\end{array}$ & E5564 & $\begin{array}{l}\text { ischemia and } \\
\text { reperfusion }\end{array}$ \\
\hline & TLR9 & COV08-0064 & acetaminophen \\
\hline & IL17A & IL17A antibody & $\begin{array}{l}\text { S. japonicum; } \\
\text { NASH }\end{array}$ \\
\hline \multirow[t]{3}{*}{$\begin{array}{l}\text { Nox/ROS } \\
\text { signaling }\end{array}$} & $\begin{array}{l}\text { NOX1/NOX4 } \\
\text { inhibitor }\end{array}$ & GKT137831 & $\begin{array}{l}\text { CCl4; BDL; } \\
\text { Fast-food Diet }\end{array}$ \\
\hline & antioxidant & Anthocyanin & $\begin{array}{l}\text { Acetaminophen; } \\
\text { BDL; Alcohol }\end{array}$ \\
\hline & antioxidant & $\beta$-Lapachone & $\begin{array}{l}\text { alcoholic fatty liver } \\
\text { disease }\end{array}$ \\
\hline Hh signaling & $\begin{array}{l}\text { Progenitor } \\
\text { response }\end{array}$ & & CCl4; MCD; DDC \\
\hline \multirow[t]{6}{*}{$\begin{array}{l}\text { Myofibroblasts } \\
\text { Activation }\end{array}$} & $\begin{array}{l}\text { TGF- } \beta \\
\text { antibody }\end{array}$ & 1D11 & TAA \\
\hline & CTGF siRNA & NA & $\mathrm{CCl} 4$ \\
\hline & $\begin{array}{l}\text { Hh signaling } \\
\text { antagonist }\end{array}$ & GDC-0449 & BDL; NASH \\
\hline & $\begin{array}{l}\text { Hh signaling } \\
\text { antagonist }\end{array}$ & CYA & BDL \\
\hline & $\begin{array}{l}\text { S1P } \\
\text { antagonist }\end{array}$ & suramin & CCI4; BDL; TAA \\
\hline & $\begin{array}{l}\text { LOXL2 } \\
\text { antibody }\end{array}$ & AB0023 & $\mathrm{CCl} 4$ \\
\hline
\end{tabular}

$\overline{M C D}$, methionine-choline deficient diet; DDC, 3,5,-diethoxycarbonyl-1,4-dihydrocollidine diet; TAA, thioacetamide.

antifibrogenic and profibrolytic effects (Popov et al., 2008), which might serve as a target for anti-fibrosis therapy.

\section{DAMAGED PARENCHYMAL CELLS RECRUIT INFLAMMATORY CELLS TO THE LIVER}

Endogenous damage-associated molecular patterns (DAMPS) released or leaked from dying hepatocytes act as danger signals recruiting immune cells to the site of injury and initiating inflammatory response (Kubes and Mehal, 2012). 
A large variety DAMPS have been identified, including nucleic acids, proteins [for example, high mobility group box-1 (HMGB1)], and cellular components [for example, adenosine triphosphate, (ATP)]. It has been shown that ATP released from necrotic hepatocytes generates an inflammatory microenvironment attracting neutrophils to the liver sinusoids via $\mathrm{P} 2 \mathrm{X7R}$, a sensor monitoring the release of ATP at inflammation sites, in a murine hepatic necrosis model by localized thermal injury (McDonald et al., 2010). Neutrophil recruitment is significantly reduced in response to tissue injury either by blocking $\mathrm{P} 2 \mathrm{X} 7$ receptor or by genetic deficiency of $P 2 \times 7 r^{-/-}$in mice (McDonald et al., 2010). The specific P2X7 antagonist, A438079, could markedly reduce acetaminopheninduced necrosis (Hoque et al., 2012) and alive CCl4induced liver inflammation and injury (Huang et al., 2014). Although ATP signals initiate neutrophil adhesion to liver sinusoid, it is the chemokines and mitochondrial contain DAMPs, including formyl-peptide receptor 1 (FPR1), that guide and direct neutrophils migration through health tissue toward injured foci (McDonald et al., 2010). CXCR2-FPR1 antagonism can block neutrophil infiltration and hepatotoxicity in acetaminophen-induced liver injury (Marques et al., 2012). These findings suggest blocking P2X7R and/or CXCR2-FPR1 could be a promising therapeutic approach to control liver inflammation.

The HMGB1 is a nonhistone nuclear protein that facilitates regulatory proteins binding to DNA. HGMB1 is constitutively expressed by most of the cells and will be released under injury and death. HGMB1 is highly induced during liver injury (Ge et al., 2014) and contributes to inflammation through binding to TLR4 (McDonald et al., 2015). It is proposed that HMGB1 may not have a direct proinflammatory effect but acts with other proinflammatory mediators such as lipopolysaccharide (LPS; Bianchi, 2009). LPS, a cell-wall component of Gram-negative bacteria, is among the strongest known inducers of inflammation. It has been shown that patients suffered from chronic liver disease had altered gut microbiota and intestinal permeability resulting in releasing bacterial endotoxins, including LPS, to the circulation (Cesaro et al., 2011; Hartmann et al., 2013; Brenner et al., 2015). The leaky gut further induces and stimulates the progression of liver inflammation in addition to the direct injury. As the receptor of HMGB1 and LPS, TLR4 increases TGF- $\beta 1$ production by Kupffer cells and activates HSCs promoting liver fibrosis (Federico et al., 2015). An inhibitor of TLR4, Eritoran tetrasodium (E5564), can prevent the gut barrier permeability and reduce liver damage by lower IL-6 level and less NF- $\kappa$ B activation in hemorrhagic shock mice with resuscitation (Korff et al., 2013). Pharmacological inhibition of TLR4 by Eritoran tetrasodium ameliorates liver injury through blocking HMGB1-mediated inflammatory signaling in ischemia and reperfusion mice (McDonald et al., 2015) In addition, both bacterial DNA and mitochondrial DNA and nuclear DNA released by damaged hepatocyte can activate TLR9 and induce a number of cellular immune responses (Kubes and Mehal, 2012). A specific antagonist of TLR9, COV080064, could limit the sterile inflammation in rat and mouse models of acute liver injury and acute pancratitis (Hoque et al., 2013). So, the antagonists of TLRs provide us new options of combination drug therapy for controlling liver inflammation.

Th17 cells are derived from Naive CD4 ${ }^{+} \mathrm{T}$ cells, which are rare in normal liver, but accumulate in the portal areas around bile ducts in chronic liver diseases (Wang et al., 2011; Oo et al., 2012). Th17 cells express CCL20, a ligand for CCR6. Using cytokine-treated human cholangiocytes, CCL20 could induce CCR6-dependent migration of Th17 cells (Oo et al., 2012), which might be one of the mechanisms for inflammatory cells recruiting to the liver. IL17 expressed by Th17 cells activates Kupffer cells to produce proinflammatory and profibrotic cytokines for fibrogenesis, and directly increase the expression of collagen, $\alpha$-SMA, TGF- $\beta$ in HSCs (Meng et al., 2012). IL-17 monoclonal antibody ameliorates hepatic granulomatous inflammation through downregulation of inflammatory cytokines and recruitment of neutrophils in mouse infected with Schistosoma japonicum (S. japonicum) larvae (Zhang et al., 2012). And neutralization of IL-17 in NASH mice ameliorates LPS-induced inflammatory cell infiltrating into the liver (Tang et al., 2011). Antibodies against IL17A has been used in phase II-III clinical trials to establish their therapeutic effects in autoimmune diseases (Schuppan and Kim, 2013), yet no information is available for clinical trials on liver fibrosis now.

\section{APOPTOTIC HEPATOCYTES ACTIVATE HSCs THROUGH Nox/ROS SIGNALING}

Ongoing hepatocyte apoptosis or necrosis leads to increase in ROS production and facilitates HSCs activation and migration, which is one of the characteristics of chronic liver disease that triggers liver fibrogenesis. Nicotinamide adenine dinucleotide phosphate $(\mathrm{NADPH})$ oxidase $(\mathrm{NOX})$ produces reactive oxygen species (ROS) via transferring electron from nicotinamide adenine dinucleotide phosphate to molecular oxygen, which is different from other redox enzymes that produce superoxide as a byproduct. The mammalian NOX family is composed of seven isoforms: NOX1, NOX2, NOX3, NOX4, NOX5, DUOX1, and DUOX2, which are distinctively expressed in specific cell types in the liver. HSCs express three Nox isoforms, Nox1, Nox2, Nox 3 (Paik et al., 2014). HSCs from $\mathrm{p} 47^{\text {phox }}$ deficient mice (without a regulatory component of NOX) fail to generate ROS in response to angiotensin II, platelet derived growth factor (PDGF), leptin, or apoptotic bodies, and $\mathrm{p} 47^{\mathrm{phox}}$ deficient mice demonstrate reduced liver fibrosis after BDL or the hepatotoxin CCl4. (De Minicis and Brenner, 2007; De Minicis et al., 2010). Since NOX1 and NOX4 are expressed in $\alpha$-SMA positive activated HSCs, GKT137831, a potent dual NOX1/NOX4 inhibitor, attenuates ROS production and inhibits activation of HSCs (Paik et al., 2014). In vivo experiments show that GKT137831 could suppress ROS production, liver inflammation and ameliorate CCl4-, BDL-, and Fast-Food Dietinduced liver fibrosis (Aoyama et al., 2012; Jiang et al., 2012; Bettaieb et al., 2015).

Although hepatocyts express many isoforms of Nox, the development of steatosis by a high-fat, methionine and 
choline-deficient (MCD) diet is independent from Nox activation in hepatocytes. In steatosis, the majority of ROS production may derive from hepatocellular lipid deposition and subsequent peroxidation. Anthocyanin, a plant-derived antioxidant, could reduce oxidative stress, relieve hepatic inflammation, and protect hepatocytes against injury, indicating its potential antifibrotic effects (Choi et al., 2009; Hou et al., 2010; Donepudi et al., 2012). Administration of beta-Lapachone (3,4dihydro-2,2-dimethyl-2H-naphthol[1,2-b]pyran-5,6-dione), a natural compound extracted from the bark of the lapacho tree (Tabebuia avellanedae), upregulates apoB100 synthesis and lipid mobilization via modulation of $\mathrm{NAD}(+) / \mathrm{NADH}$ ratio to activate AMPK signaling (Shin et al., 2014). Although vitamin E may reduce the liver oxidative stress and the fibrosis development, administration vitamin E supplementation does not consistently result in protection from liver injury. Multicenter, long-term clinical trials are still needed to evaluate the role of antioxidants in NASH.

\section{DYING HEPATOCYTES ACTIVATE HEPATIC PROGENITORS THROUGH Hh SIGNALING}

Hh signal released by dying hepatocyte could activate the compensatory outgrowth of hepatic progenitors, which are involved in liver regeneration (Jung et al., 2010). As a Hh target, osteopontin is highly expressed in fibrotic liver tissue and influences the function of hepatic progenitors (Coombes et al., 2015). And neutralization of osteopontin could suppress progenitor cell response and attenuate liver fibrosis in $\mathrm{CCl} 4$, methionine-choline deficient diet (MCD) and 3,5,-diethoxycarbonyl-1,4-dihydrocollidine diet (DDC) mice (Coombes et al., 2015).

\section{TREATING LIVER FIBROSIS BY TARGETING MYOFIBROBLAST ACTIVATION}

Chronic inflammation is linked to liver fibrosis through activating the fibrogenetic effector cells, HSCs, portal fibroblasts, bone marrow-derived fibrocytes, and mesenchymal stem cells. HSCs are the major source of hepatic myofibroblasts during development of liver fibrosis under different etiologies (Mederacke et al., 2013). Portal fibroblasts play a less role in the pathogenesis of liver fibrosis than HSCs because they were implicated to pathogenesis of cholestatic liver injury (Wells, 2014). Fibrocytes with dual characteristics of fibroblasts and hematopoietic cells migrate to the injured liver in response to $\mathrm{BDL}$ and CCl4-damaged liver and comprise about $5 \%$ of the collagen type I expressing myofibroblasts (Kisseleva et al., 2006; Scholten et al., 2011). Bone marrow-derived mesenchymal stem cells could also be recruited to the injured liver and facilitate fibrogenesis (Russo et al., 2006; Li et al., 2009). Although epithelial-mesenchymal transition of hepatocytes and cholangiocytes has been reported to be another origin of myofibroblasts (Omenetti et al., 2007; Zeisberg et al., 2007; Nitta et al., 2008; Syn et al., 2009), recent studies using cell fate mapping detect only minimal or no contribution of EMT by hepatocytes, cholangiocytes, or hepatic progenitors to myofibroblasts (Scholten et al., 2010; Taura et al., 2010; Chu et al., 2011). And, although endothelial cell injury and neovascularization play a critical role in liver fibrosis, the transition of endothelial cells to mesenchymal cells (EndMT) giving rise myofibroblasts is still not definitively resolved. So, anti-fibrotic therapy targeting the myofibroblast activation process of HSCs, portal fibroblasts, fibrocytes, and mesenchymal stem cells might be more useful than blocking EMT or EndMT.

After engulfment of apoptotic bodies, Kupffer cells are stimulated to produce TGF- $\beta 1$ (Szondy et al., 2003), which is a potent cytokine to activate HSCs, fibrocytes, and mesenchymal stem cells into myofibroblasts (Kisseleva et al., 2006; Li et al., 2009; Meindl-Beinker et al., 2012). Although TGF- $\beta$ is one of the most potent stimuli of extracellular matrix synthesis, suppressing its expression remains a major challenge of antifibrotic therapy, since systemic blocking of TGF- $\beta 1$ can provoke inflammation and increase the risk of neoplasia. Neutralization TGF- $\beta$ in animal models inhibits liver fibrosis and reduces the risk in developing cholangiocarcinoma (Fan et al., 2013; Ling et al., 2013). Fresolimumab (GC1008) is a human anti-TGF$\beta 1$ monoclonal antibody that neutralizes all isoform of TGF$\beta$. In patients with advanced malignant melanoma and renal cell carcinoma, fresolimumab demonstrated acceptable safety and preliminary evidence of antitumor activity (Trachtman et al., 2011; Morris et al., 2014; Lacouture et al., 2015). Using radio-labeled (89)Zr-conjugated fresolimumab for PET to analyze TGF- $\beta$ expression, GC1008 accumulated in primary tumors and metastases in a manner similar to IgG, and (89) $\mathrm{Zr}$-fresolimumab uptake is seen in sites of tumor ulceration and in scar tissue, where TGF- $\beta$ is highly active (Oude Munnink et al., 2011). Although there is phase II clinical trial ongoing of fresolimumab, optimal strategies are still needed to restrict it to the fibrotic milieu. TGF- $\beta$ transduces its signal to target genes through the ALK5 ser/thr kinase receptor. GW6604 (2-phenyl-4(3-pyridin-2-yl-1H-pyrazol-4-yl)-pyridine), an ALK5 inhibitor, inhibits the transcription and deposition of extracellular matrix and improves the deterioration of liver function in mice (de Gouville et al., 2005). Yet, considering of the pleiotropic effects of TGF- $\beta$, treatment with an ALK5 inhibitor should be carefully examined to avoid the unwanted effects (de Gouville and Huet, 2006).

As a TGF- $\beta$ target gene, CTGF is considered as a central mediator which is specific for promoting fibrogenensis. It has been reported that inhibition of CTGF expression by siRNA prevents $\mathrm{CCl} 4$-induced liver fibrosis and can induce regression of liver fibrosis (Hao et al., 2014). A human monoclonal antibody to CTGF, FG-3019, has been investigated in various animal models (e.g., liver fibrosis, diabetes, pulmonary fibrosis) and demonstrated a reduction and regression of fibrogenesis. FG3019 binds to the second domain of human CTGF and is currently under phase II drug investigation for the treatment of liver fibrosis (Lipson et al., 2012; Hauff et al., 2015).

Platelet-derived growth factor (PDGF) is the most potent mitogen for HSC. Imatinib mesylate, a clinically used PDGF receptor tyrpsine kinase inhibitor, attenuates liver fibrosis at 
early stages, but does not prevent advanced liver fibrosis in animal experiments (Yoshiji et al., 2005; Neef et al., 2006). PTPRO (protein tyrosine phosphatase, receptor type O) shRNA significantly neutralized PDGF-BB-induced HSC proliferation and myofibroblast marker expression through downregulated phosphorylation of extracellular signal-regulated kinase (ERK) and AKT. PTPRO knockout mice [PTPRO(-/-)] have attenuated liver injury, release of inflammatory factors, tissue remodeling, and liver fibrosis in fibrogenesis induced by $\mathrm{BDL}$ or carbon tetrachloride (CCl4) administration (Zhang et al., 2015).

Not only does Hh signaling participate in cholangiocytechemokine secretion and progenitor response, but also it is involved in liver injury and inflammation after ischemia reperfusion and BDL (Pratap et al., 2010, 2011). Pharmacological inhibition of Hedgehog signaling by vismodegib (GDC-0449) and CYA could attenuate BDL-induced liver fibrosis (Pratap et al., 2012). And vismodegib relieves hepatic inflammation and liver fibrosis in a mouse nutrient excess model of NASH (Hirsova et al., 2013).

Sphingosine 1-phosphate (S1P) is a multifunctional mediator with increased synthesis in the liver following acute and chronic liver injury (Li et al., 2009, 2011), while its concentration remains a relative low level in the bone marrow. This S1P gradient between liver and bone marrow drives the recruitment of bone marrow-derived mesenchymal stem cells into the circulation and into the liver afterwards. Selective S1P receptor antagonist, suramin, has anti-fibrotic effects in $\mathrm{CCl} 4$ and BDL liver fibrosis (Li et al., 2009) and hepatoprotective and antitumor activities in TAA-induced liver injury (Tayel et al., 2014).

Inhibitors of receptor tyrosine kinase and Ser/Thr kinase also demonstrate some anti-fibrosis effects. Multitargeted receptor tyrosine kinase inhibitor Sorafenib, which has been approved for the treatment of advanced renal cell carcinoma and hepatocellular carcinoma (HCC), and Sunitinib, can improve

TABLE 2 | Ongoing clinical studies of antifibrotic drugs.

\begin{tabular}{|c|c|c|c|c|c|c|}
\hline Targets & Mechanism & Intervention & NCT no. & $\begin{array}{l}\text { Disease } \\
\text { condition }\end{array}$ & Phase & Status \\
\hline \multirow[t]{5}{*}{ Injured hepatocytes } & $\begin{array}{l}\text { Pan-caspase } \\
\text { inhibitor }\end{array}$ & IDN 6556 & NCT02230683 & $\begin{array}{l}\text { Liver cirrhosis with } \\
\text { portal } \\
\text { hypertension }\end{array}$ & Phase 2 & Complete \\
\hline & $\begin{array}{l}\text { Pan-caspase } \\
\text { inhibitor }\end{array}$ & IDN 6556 & NCT02077374 & NAFLD & Phase 2 & Complete \\
\hline & $\begin{array}{l}\text { Pan-caspase } \\
\text { inhibitor }\end{array}$ & IDN 6556 & NCT00088140 & Chronic HCV & Phase 2 & Complete \\
\hline & $\begin{array}{l}\text { Pan-caspase } \\
\text { inhibitor }\end{array}$ & IDN 6556 & NCT02230670 & Liver cirrhosis & Phase 2 & Active, not recruiting \\
\hline & $\begin{array}{l}\text { Pan-caspase } \\
\text { inhibitor }\end{array}$ & IDN 6556 & NCT01912404 & Severe AH & Phase 2 & Terminated \\
\hline Cholangiocyte proliferation & hedgehog inhibitor & LDE225 & NCT02151864 & $\begin{array}{l}\text { HCC and liver } \\
\text { cirrhosis }\end{array}$ & Phase 1 & Recruiting \\
\hline Nox/ROS & Anti-oxidant & Vitamin E & NCT01792115 & NAFLD & Phase 2 & Recruiting \\
\hline Signaling & Anti-oxidant & Anthocyanin & NCT01940263 & NAFLD & Phase 0 & Complete \\
\hline \multirow[t]{4}{*}{ Myofibroblasts } & CTGF antibody & FG-3019 & NCT01217632 & $\begin{array}{l}\text { Liver Fibrosis Due } \\
\text { to HBV }\end{array}$ & Phase 2 & Active, not recruiting \\
\hline & LOXL antibody & Simtuzumab & NCT01452308 & Liver Fibrosis & Phase 2 & Complete \\
\hline & LOXL antibody & Simtuzumab & NCT01672879 & $\mathrm{NASH}$ & Phase 2 & Active, not recruiting \\
\hline & LOXL antibody & Simtuzumab & NCT01672853 & PSC & Phase 2 & Active, not recruiting \\
\hline \multirow[t]{6}{*}{ Mesenchymal stem cells } & $\begin{array}{l}\text { Umbilical cord } \\
\text { MSCs }\end{array}$ & Transplantation & NCT01724398 & Liver failure & $\begin{array}{l}\text { Phase } 1 \\
\text { Phase } 2\end{array}$ & Unknown \\
\hline & $\begin{array}{l}\text { Umbilical cord } \\
\text { MSCs }\end{array}$ & Transplantation & NCT01218464 & Liver failure & $\begin{array}{l}\text { Phase } 1 \\
\text { Phase } 2\end{array}$ & Unknown \\
\hline & Autologous MSCs & Transplantation & NCT01741090 & $\begin{array}{l}\text { Alcoholic Liver } \\
\text { Cirrhosis }\end{array}$ & Phase 2 & Unknown \\
\hline & $\begin{array}{l}\text { Umbilical cord } \\
\text { MSCs } \\
\text { Bone marrow } \\
\text { MSCs }\end{array}$ & Transplantation & NCT01844063 & Liver failure & $\begin{array}{l}\text { Phase } 1 \\
\text { Phase } 2\end{array}$ & recruiting \\
\hline & Autologous MSCs & Transplantation & NCT00420134 & $\begin{array}{l}\text { Liver failure, } \\
\text { cirrhosis }\end{array}$ & $\begin{array}{l}\text { Phase } 1 \\
\text { Phase } 2\end{array}$ & Complete \\
\hline & Autologous MSCs & Transplantation & NCT00956891 & Liver failure & $\begin{array}{l}\text { Phase } 1 \\
\text { Phase } 2\end{array}$ & Complete \\
\hline
\end{tabular}


experimental hepatic fibrosis, inflammation, and angiogenesis (Tugues et al., 2007; Mejias et al., 2009). SiRNA of transient receptor potential melastatin 7 (TRPM7), a non-selective cation channel with protein serine/threonine kinase activity, attenuates TGF- $\beta 1$-induced expression of myofibroblast markers, increases the ratio of MMPs/TIMPs, and decrease the phosphorylation of Smad2 and Smad3 associated collagen production (Fang et al., 2013, 2014). Hepatic nuclear factor kappa B (NF- $\kappa \mathrm{B})$-inducing kinase (NIK), a Ser/Thr kinase, which is increased in injured livers in both mice and humans, induces hepatocyte injury, activates bone marrow-derived macrophages, and leads to liver fibrosis, and this might serve as a candidate for liver fibrosis therapy (Shen et al., 2014).

No matter what the origin of myofibroblasts is, the common feature of them is expressing extracellular matrix. In liver fibrosis, type I collagen is the most prominent increased components of extracellular matrix. The cross-linking of type I collagen is also increased, which is modulated by the matrix enzyme lysyl oxidase-like-2 (LOXL2). Although blocking collagens have unwanted off-target effects, inhibition of LOXL2 by a monoclonal antibody (AB0023) reduces the production of cytokines, attenuates TGF- $\beta$ signaling, and inhibits the activate fibroblasts (Barry-Hamilton et al., 2010). Similar to AB0023, another humanized monoclonal LOXL2 antibody (GS-6624) is in randomized, double blind, phase II clinical trials to treat NASH and PSC (Schuppan and Kim, 2013).

\section{TRANSPLANTATION OF MESENCHYMAL STEM CELLS TO RELIEVE LIVER FIBROSIS}

Mesenchymal stem cells, which reside in various tissue, such as bone marrow, umbilical cord blood, adipose tissue and others, can differentiate into multiple cell lineages in vitro, including hepatocyte (Ye et al., 2015). Yet, few engraft human cells could be found in the liver after transplantation of human mesenchymal stem cells into the sublethally irradiated NOD/SCID mice exposed to acute or chronic CCl4 injury (di Bonzo et al., 2008).

\section{REFERENCES}

Anstee, Q. M., Concas, D., Kudo, H., Levene, A., Pollard, J., Charlton, P., et al. (2010). Impact of pan-caspase inhibition in animal models of established steatosis and non-alcoholic steatohepatitis. J. Hepatol. 53, 542-550. doi: 10.1016/j.jhep.2010.03.016

Aoyama, T., Paik, Y. H., Watanabe, S., Laleu, B., Gaggini, F., Fioraso-Cartier, L., et al. (2012). Nicotinamide adenine dinucleotide phosphate oxidase in experimental liver fibrosis: GKT137831 as a novel potential therapeutic agent. Hepatology 56, 2316-2327. doi: 10.1002/hep.25938

Barreyro, F. J., Holod, S., Finocchietto, P. V., Camino, A. M., Aquino, J. B., Avagnina, A., et al. (2015). The pan-caspase inhibitor Emricasan (IDN6556) decreases liver injury and fibrosis in a murine model of non-alcoholic steatohepatitis. Liver Int. 35, 953-966. doi: 10.1111/liv.12570

Barry-Hamilton, V., Spangler, R., Marshall, D., McCauley, S., Rodriguez, H. M., Oyasu, M., et al. (2010). Allosteric inhibition of lysyl oxidase-like-2 impedes the development of a pathologic microenvironment. Nat. Med. 16, 1009-1017. doi: $10.1038 / \mathrm{nm} .2208$

Bettaieb, A., Jiang, J. X., Sasaki, Y., Chao, T. I., Kiss, Z., Chen, X., et al. (2015). Hepatocyte nicotinamide adenine dinucleotide phosphate reduced
Although endogenous mesenchymal stem cells contribute to liver fibrogenesis during liver injury as described previously, recent studies have demonstrated that exogenous transplantation of mesenchymal stem cells have immunomodulation, inflammation suppression and antifibrogenic effects (Lin et al., 2011; Wang et al., 2014; Christ et al., 2015). Many clinical investigations on the safety and efficacy of mesenchymal stem cells for treatment of liver failure and liver cirrhosis are under phase I and phase II studies (Table 2).

\section{CONCLUSION}

Currently, there are many potential antifibrotic targets obtained from animal experiments (Table 1), yet most of the therapies are still in preclinical evaluation stages (Table 2). Since both animal experiments and clinical studies have revealed that liver fibrosis, even early cirrhosis, is reversible, treating patients by combined therapies on underline etiology and fibrosis simultaneously might expedite the regression of liver fibrosis and promote liver regeneration. In the circumstance that the underline etiology of liver fibrosis could not be eradicated, therapies on liver fibrosis might help restrict the disease progression to cirrhosis and reduce the risk of cirrhosis related complication. In the future, the elucidation of the molecular steps of regression of liver fibrosis might provide new preventive and therapeutic strategies for fibrosis even cirrhosis patients.

\section{AUTHOR CONTRIBUTIONS}

All authors listed, have made substantial, direct and intellectual contribution to the work, and approved it for publication.

\section{ACKNOWLEDGMENTS}

NIH 2 P50 AA011999, 5 P42 ES010337, 5 U01 AA021856; Beijing Nova Program Z111107054511064.

oxidase 4 regulates stress signaling, fibrosis, and insulin sensitivity during development of Steatohepatitis in mice. Gastroenterology 149, 468.e10-480.e10. doi: 10.1053/j.gastro.2015.04.009

Bianchi, M. E. (2009). HMGB1 loves company. J. Leukoc. Biol. 86, 573-576. doi: 10.1189/jlb.1008585

Brenner, D. A., Paik, Y. H., and Schnabl, B. (2015). Role of gut microbiota in liver disease. J. Clin. Gastroenterol. 49(Suppl. 1), S25-S27. doi: 10.1097/MCG.0000000000000391

Canbay, A., Feldstein, A., Baskin-Bey, E., Bronk, S. F., and Gores, G. J. (2004). The caspase inhibitor IDN-6556 attenuates hepatic injury and fibrosis in the bile duct ligated mouse. J. Pharmacol. Exp. Ther. 308, 1191-1196. doi: 10.1124/jpet.103.060129

Cesaro, C., Tiso, A., Del Prete, A., Cariello, R., Tuccillo, C., Cotticelli, G., et al. (2011). Gut microbiota and probiotics in chronic liver diseases. Dig. Liver Dis. 43, 431-438. doi: 10.1016/j.dld.2010. 10.015

Chen, G., Zhang, L., Chen, L., Wang, H., Zhang, Y., and Bie, P. (2013). Role of integrin $\alpha v \beta 6$ in the pathogenesis of ischemia-related biliary fibrosis after liver transplantation. Transplantation 95, 1092-1099. doi: 10.1097/TP.0b013e3182884866 
Choi, J. H., Choi, C. Y., Lee, K. J., Hwang, Y. P., Chung, Y. C., and Jeong, H. G. (2009). Hepatoprotective effects of an anthocyanin fraction from purple-fleshed sweet potato against acetaminophen-induced liver damage in mice. J. Med. Food. 12, 320-326. doi: 10.1089/jmf.2007.0691

Christ, B., Brückner, S., and Winkler, S. (2015). The Therapeutic Promise of mesenchymal stem cells for liver restoration. Trends Mol. Med. 21, 673-686. doi: 10.1016/j.molmed.2015.09.004

Chu, A. S., Diaz, R., Hui, J. J., Yanger, K., Zong, Y., Alpini, G., et al. (2011). Lineage tracing demonstrates no evidence of cholangiocyte epithelial-to-mesenchymal transition in murine models of hepatic fibrosis. Hepatology 53, 1685-1695. doi: 10.1002/hep. 24206

Coombes, J. D., Swiderska-Syn, M., Dollé, L., Reid, D., Eksteen, B., Claridge, L., et al. (2015). Osteopontin neutralisation abrogates the liver progenitor cell response and fibrogenesis in mice. Gut 64, 1120-1131. doi: 10.1136/gutjnl2013-306484

de Gouville, A. C., Boullay, V., Krysa, G., Pilot, J., Brusq, J. M., Loriolle, F., et al. (2005). Inhibition of TGF-beta signaling by an ALK5 inhibitor protects rats from dimethylnitrosamine-induced liver fibrosis. Br. J. Pharmacol. 145, 166-177. doi: 10.1038/sj.bjp.0706172

de Gouville, A. C., and Huet, S. (2006). Inhibition of ALK5 as a new approach to treat liver fibrotic diseases. Drug News Perspect. 19, 85-90. doi: 10.1358/dnp.2006.19.2.977444

De Minicis, S., and Brenner, D. A. (2007). NOX in liver fibrosis. Arch. Biochem. Biophys. 462, 266-272. doi: 10.1016/j.abb.2007.04.016

De Minicis, S., Seki, E., Paik, Y. H., Osterreicher, C. H., Kodama, Y., Kluwe, J., et al. (2010). Role and cellular source of nicotinamide adenine dinucleotide phosphate oxidase in hepatic fibrosis. Hepatology 52, 1420-1430. doi: 10.1002/hep.23804

di Bonzo, L. V., Ferrero, I., Cravanzola, C., Mareschi, K., Rustichell, D., Novo, E., et al. (2008). Human mesenchymal stem cells as a two-edged sword in hepatic regenerative medicine: engraftment and hepatocyte differentiation versus profibrogenic potential. Gut 57, 223-231. doi: 10.1136/gut.2006.111617

Dixon, L. J., Berk, M., Thapaliya, S., Papouchado, B. G., and Feldstein, A. E. (2012). Caspase-1-mediated regulation of fibrogenesis in diet-induced steatohepatitis. Lab. Invest. 92, 713-723. doi: 10.1038/labinvest.2012.45

Donepudi, A. C., Aleksunes, L. M., Driscoll, M. V., Seeram, N. P., and Slitt, A. L. (2012). The traditional ayurvedic medicine, Eugenia jambolana (Jamun fruit), decreases liver inflammation, injury and fibrosis during cholestasis. Liver Int. 32, 560-573. doi: 10.1111/j.1478-3231.2011.02724.x

Fan, X., Zhang, Q., Li, S., Lv, Y., Su, H., Jiang, H., et al. (2013). Attenuation of $\mathrm{CCl} 4$-induced hepatic fibrosis in mice by vaccinating against TGF- $\beta 1$. PLoS ONE 8:e82190. doi: 10.1371/journal.pone.0082190

Fang, L., Huang, C., Meng, X., Wu, B., Ma, T., Liu, X., et al. (2014). TGF$\beta 1$-elevated TRPM7 channel regulates collagen expression in hepatic stellate cells via TGF- $\beta 1 /$ Smad pathway. Toxicol. Appl. Pharmacol. 280, 335-344. doi: 10.1016/j.taap.2014.08.006

Fang, L., Zhan, S., Huang, C., Cheng, X., Lv, X., Si, H., et al. (2013). TRPM7 channel regulates PDGF-BB-induced proliferation of hepatic stellate cells via PI3K and ERK pathways. Toxicol. Appl. Pharmacol. 272, 713-725. doi: 10.1016/j.taap.2013.08.009

Federico, A., Dallio, M., Godos, J., Loguercio, C., and Salomone, F. (2015). Targeting gut-liver axis for the treatment of nonalcoholic steatohepatitis: translational and clinical evidence. Transl. Res. 167, 116-124. doi: 10.1016/j. trsl.2015.08.002

Ge, X., Antoine, D. J., Lu, Y., Arriazu, E., Leung, T. M., Klepper, A. L., et al. (2014). High mobility group box-1 (HMGB1) participates in the pathogenesis of alcoholic liver disease (ALD). J. Biol. Chem. 289, 22672-22691. doi: 10.1074/jbc.M114.552141

Hao, C., Xie, Y., Peng, M., Ma, L., Zhou, Y., Zhang, Y., et al. (2014). Inhibition of connective tissue growth factor suppresses hepatic stellate cell activation in vitro and prevents liver fibrosis in vivo. Clin. Exp. Med. 14, 141-150. doi: 10.1007/s10238-013-0229-6

Hartmann, P., Chen, P., Wang, H. J., Wang, L., McCole, D. F., Brandl, K., et al. (2013). Deficiency of intestinal mucin-2 ameliorates experimental alcoholic liver disease in mice. Hepatology 58, 108-119. doi: 10.1002/hep.26321

Hauff, P., Gottwald, U., and Ocker, M. (2015). Early to Phase II drugs currently under investigation for the treatment of liver fibrosis. Expert Opin. Investig. Drugs 24, 309-327. doi: 10.1517/13543784.2015.997874
Hirsova, P., Ibrahim, S. H., Bronk, S. F., Yagita, H., and Gores, G. J. (2013). Vismodegib suppresses TRAIL-mediated liver injury in a mouse model of nonalcoholic steatohepatitis. PLoS ONE 8:e70599. doi: 10.1371/journal.pone.0070599

Hoque, R., Farooq, A., Malik, A., Trawick, B. N., Berberich, D. W., McClurg, J. P., et al. (2013). A novel small-molecule enantiomeric analogue of traditional (-)-morphinans has specific TLR9 antagonist properties and reduces sterile inflammation-induced organ damage. J. Immunol. 190, 4297-4304. doi: 10.4049/jimmunol.1202184

Hoque, R., Sohail, M. A., Salhanick, S., Malik, A. F., Ghani, A., Robson, S. C., et al. (2012). P2X7 receptor-mediated purinergic signaling promotes liver injury in acetaminophen hepatotoxicity in mice. Am. J. Physiol. Gastrointest. Liver Physiol. 302, G1171-G1179. doi: 10.1152/ajpgi.00352.2011

Hou, Z., Qin, P., and Ren, G. (2010). Effect of anthocyanin-rich extract from black rice (Oryza sativa L. Japonica) on chronically alcohol-induced liver damage in rats. J Agric. Food Chem. 58, 3191-3196. doi: 10.1021/jf904407x

Huang, C., Yu, W., Cui, H., Wang, Y., Zhang, L., Han, F., et al. (2014). P2X7 blockade attenuates mouse liver fibrosis. Mol. Med. Rep. 9, 57-62. doi: 10.3892/mmr.2013.1807

Jiang, J. X., Chen, X., Serizawa, N., Szyndralewiez, C., Page, P., Schröder, K., et al. (2012). Liver fibrosis and hepatocyte apoptosis are attenuated by GKT137831, a novel NOX4/NOX1 inhibitor in vivo. Free Radic. Biol. Med. 53, 289-296. doi: 10.1016/j.freeradbiomed.2012.05.007

Jung, Y., Witek, R. P., Syn, W. K., Choi, S. S., Omenetti, A., Premont, R., et al. (2010). Signals from dying hepatocytes trigger growth of liver progenitors. Gut 59, 655-665. doi: 10.1136/gut.2009.204354

Kim do, Y., Chung, S. I., Ro, S. W., Paik, Y. H., Lee, J. I., Jung, M. K., et al. (2013). Combined effects of an antioxidant and caspase inhibitor on the reversal of hepatic fibrosis in rats. Apoptosis 18, 1481-1491. doi: 10.1007/s10495-01 3-0896-5

Kisseleva, T., Uchinami, H., Feirt, N., Quintana-Bustamante, O., Segovia, J. C., Schwabe, R. F., et al. (2006). Bone marrow-derived fibrocytes participate in pathogenesis of liver fibrosis. J. Hepatol. 45, 429-438. doi: 10.1016/j.jhep.2006.04.014

Korff, S., Loughran, P., Cai, C., Lee, Y. S., Scott, M., and Billiar, T. R. (2013). Eritoran attenuates tissue damage and inflammation in hemorrhagic shock/trauma. J. Surg. Res. 184, e17-e25. doi: 10.1016/j.jss.2013. 03.023

Kubes, P., and Mehal, W. Z. (2012). Sterile inflammation in the liver. Gastroenterology 143, 1158-1172. doi: 10.1053/j.gastro.2012.09.008

Lacouture, M. E., Morris, J. C., Lawrence, D. P., Tan, A. R., Olencki, T. E., Shapiro, G. I., et al. (2015). Cutaneous keratoacanthomas/squamous cell carcinomas associated with neutralization of transforming growth factor $\beta$ by the monoclonal antibody fresolimumab (GC1008). Cancer Immunol. Immunother. 64, 437-446. doi: 10.1007/s00262-015-1653-0

Li, C., Kong, Y., Wang, H., Wang, S., Yu, H., Liu, X., et al. (2009). Homing of bone marrow mesenchymal stem cells mediated by sphingosine 1phosphate contributes to liver fibrosis. J. Hepatol. 50, 1174-1183. doi: 10.1016/j.jhep.2009.01.028

Li, C., Zheng, S., You, H., Liu, X., Lin, M., Yang, L., et al. (2011). Sphingosine 1-phosphate (S1P)/S1P receptors are involved in human liver fibrosis by action on hepatic myofibroblasts motility. J. Hepatol. 54, 1205-1213. doi: 10.1016/j.jhep.2010.08.028

Lin, H., Xu, R., Zhang, Z., Chen, L., Shi, M., and Wang, F. S. (2011). Implications of the immunoregulatory functions of mesenchymal stem cells in the treatment of human liver diseases. Cell Mol. Immunol. 8, 19-22. doi: 10.1038/cmi.2010.57

Ling, H., Roux, E., Hempel, D., Tao, J., Smith, M., Lonning, S., et al. (2013). Transforming growth factor $\beta$ neutralization ameliorates pre-existing hepatic fibrosis and reduces cholangiocarcinoma in thioacetamide-treated rats. PLoS ONE 8:e54499. doi: 10.1371/journal.pone.0054499

Lipson, K. E., Wong, C., Teng, Y., and Spong, S. (2012). CTGF is a central mediator of tissue remodeling and fibrosis and its inhibition can reverse the process of fibrosis. Fibrogenesis Tissue Repair 5:S24. doi: 10.1186/1755-1536-5-S1-S24

Machado, M. V., Michelotti, G. A., Pereira, T. D., Boursier, J., Kruger, L., Swiderska-Syn, M., et al. (2014). Reduced lipoapoptosis, hedgehog pathway activation and fibrosis in caspase-2 deficient mice with nonalcoholic steatohepatitis. Gut 67, 1148-1157. doi: 10.1136/gutjnl-2014307362 
Marques, P. E., Amaral, S. S., Pires, D. A., Nogueira, L. L., Soriani, F. M., Lima, B. H., et al. (2012). Chemokines and mitochondrial products activate neutrophils to amplify organ injury during mouse acute liver failure. Hepatology 56, 1971-1882. doi: 10.1002/hep.25801

McDonald, B., Pittman, K., Menezes, G. B., Hirota, S. A., Slaba, I., Waterhouse, C. C., et al. (2010). Intravascular danger signals guide neutrophils to sites of sterile inflammation. Science 330, 362-366. doi: 10.1126/science. 1195491

McDonald, K. A., Huang, H., Tohme, S., Loughran, P., Ferrero, K., Billiar, T., et al. (2015). Toll-like receptor 4 (TLR4) antagonist eritoran tetrasodium attenuates liver ischemia and reperfusion injury through inhibition of highmobility group box protein B1 (HMGB1) Signaling. Mol. Med. 20, 639-648. doi: 10.2119/molmed.2014.00076

Mederacke, I., Hsu, C. C., Troeger, J. S., Huebener, P., Mu, X., Dapito, D. H., et al. (2013). Fate tracing reveals hepatic stellate cells as dominant contributors to liver fibrosis independent of its aetiology. Nat. Commun. 4, 2823. doi: $10.1038 /$ ncomms3823

Meindl-Beinker, N. M., Matsuzaki, K., and Dooley, S. (2012). TGF- $\beta$ signaling in onset and progression of hepatocellular carcinoma. Dig. Dis. 30, 514-523. doi: $10.1159 / 000341704$

Mejias, M., Garcia-Pras, E., Tiani, C., Miquel, R., Bosch, J., and Fernandez, M. (2009). Beneficial effects of sorafenib on splanchnic, intrahepatic, and portocollateral circulations in portal hypertensive and cirrhotic rats. Hepatology 49, 1245-1256. doi: 10.1002/hep.22758

Meng, F., Wang, K., Aoyama, T., Grivennikov, S. I., Paik, Y., Scholten, D., et al. (2012). Interleukin-17 signaling in inflammatory, Kupffer cells, and hepatic stellate cells exacerbates liver fibrosis in mice. Gastroenterology 143, 765-776. doi: 10.1053/j.gastro.2012.05.049

Morris, J. C., Tan, A. R., Olencki, T. E., Shapiro, G. I., Dezube, B. J., Reiss, M., et al. (2014). Phase I study of GC1008 (fresolimumab): a human antitransforming growth factor-beta (TGF $\beta$ ) monoclonal antibody in patients with advanced malignant melanoma or renal cell carcinoma. PLOS ONE 9:e90353. doi: 10.1371/journal.pone.0090353

Neef, M., Ledermann, M., Saegesser, H., Schneider, V., Widmer, N., Decosterd, L. A., et al. (2006). Oral imatinib treatment reduces early fibrogenesis but does not prevent progression in the long term. J. Hepatol. 44, 167-175. doi: 10.1016/j.jhep.2005.06.015

Nitta, T., Kim, J. S., Mohuczy, D., and Behrns, K. E. (2008). Murine cirrhosis induces hepatocyte epithelial mesenchymal transition and alterations in survival signaling pathways. Hepatology 48, 909-919. doi: 10.1002/hep.22397

Omenetti, A., Syn, W. K., Jung, Y., Francis, H., Porrello, A., Witek, R. P., et al. (2009). Repair-related activation of hedgehog signaling promotes cholangiocyte chemokine production. Hepatology 50, 518-527. doi: 10.1002/hep.23019

Omenetti, A., Yang, L., Li, Y. X., McCall, S. J., Jung, Y., Sicklick, J. K., et al. (2007). Hedgehog-mediated mesenchymal-epithelial interactions modulate hepatic response to bile duct ligation. Lab. Invest. 87, 499-514. doi: 10.1038/labinvest.3700537

Oo, Y. H., Banz, V., Kavanagh, D., Liaskou, E., Withers, D. R., Humphreys, E., et al. (2012). CXCR3-dependent recruitment and CCR6-mediated positioning of Th-17 cells in the inflamed liver. J. Hepatol 57, 1044-1051. doi: 10.1016/j.jhep.2012.07.008

Oude Munnink, T. H., Arjaans, M. E., Timmer-Bosscha, H., Schröder, C. P., Hesselink, J. W., Vedelaar, S. R., et al. (2011). PET with the 89Zr-labeled transforming growth factor- $\beta$ antibody fresolimumab in tumor models. J. Nucl. Med. 52, 2001-2008. doi: 10.2967/jnumed.111.092809

Paik, Y. H., Kim, J., Aoyama, T., De Minicis, S., Bataller, R., and Brenner, D. A. (2014). Role of NADPH oxidases in liver fibrosis. Antioxid. Redox Signal. 20, 2854-2872. doi: 10.1089/ars.2013.5619

Philips, G. M., Chan, I. S., Swiderska, M., Schroder, V. T., Guy, C., Karaca, G. F., et al. (2011). Hedgehog signaling antagonist promotes regression of both liver fibrosis and hepatocellular carcinoma in a murine model of primary liver cancer. PLoS ONE 6:e23943. doi: 10.1371/journal.pone.0023943

Pockros, P. J., Schiff, E. R., Shiffman, M. L., McHutchison, J. G., Gish, R. G., Afdhal, N. H., et al. (2007). Oral IDN-6556, an antiapoptotic caspase inhibitor, may lower aminotransferase activity in patients with chronic hepatitis C. Hepatology 46, 324-329. doi: 10.1002/hep.21664

Popov, Y., Patsenker, E., Stickel, F., Zaks, J., Bhaskar, K. R., Niedobitek, G., et al. (2008). Integrin alphavbeta6 is a marker of the progression of biliary and portal liver fibrosis and a novel target for antifibrotic therapies. J. Hepatol. 48, 453-464. doi: 10.1016/j.jhep.2007.11.021

Pratap, A., Panakanti, R., Yang, N., Eason, J. D., and Mahato, R. I. (2010). Inhibition of endogenous hedgehog signaling protects against acute liver injury after ischemia reperfusion. Pharm. Res. 27, 2492-2504. doi: 10.1007/s11095-0100246-Z

Pratap, A., Panakanti, R., Yang, N., Lakshmi, R., Modanlou, K. A., Eason, J. D., et al. (2011). Cyclopamine attenuates acute warm ischemia reperfusion injury in cholestatic rat liver: hope for marginal livers. Mol. Pharm. 8, 958-968. doi: $10.1021 / \mathrm{mp} 200115 \mathrm{v}$

Pratap, A., Singh, S., Mundra, V., Yang, N., Panakanti, R., Eason, J. D., et al. (2012). Attenuation of early liver fibrosis by pharmacological inhibition of smoothened receptor signaling. J. Drug Target 20, 770-782. doi: 10.3109/1061186X.2012.719900

Russo, F. P., Alison, M. R., Bigger, B. W., Amofah, E., Florou, A., Amin, F., et al. (2006). The bone marrow functionally contributes to liver fibrosis. Gastroenterology. 130, 1807-1821. doi: 10.1053/j.gastro.2006.01.036

Scholten, D., Osterreicher, C. H., Scholten, A., Iwaisako, K., Gu, G., Brenner, D. A., et al. (2010). Genetic labeling does not detect epithelial-to-mesenchymal transition of cholangiocytes in liver fibrosis in mice. Gastroenterology 139, 987-998. doi: 10.1053/j.gastro.2010.05.005

Scholten, D., Reichart, D., Paik, Y. H., Lindert, J., Bhattacharya, J., Glass, C. K., et al. (2011). Migration of fibrocytes in fibrogenic liver injury. Am. J. Pathol. 179, 189-198. doi: 10.1016/j.ajpath.2011.03.049

Schuppan, D., and Kim, Y. O. (2013). Evolving therapies for liver fibrosis. J. Clin. Invest. 123, 1887-1901. doi: 10.1172/JCI66028

Shen, H., Sheng, L., Chen, Z., Jiang, L., Su, H., Yin, L., et al. (2014). Mouse hepatocyte overexpression of NF-кB-inducing kinase (NIK) triggers fatal macrophage-dependent liver injury and fibrosis. Hepatology 60, 2065-2076. doi: $10.1002 /$ hep. 27348

Shin, S., Park, J., Li, Y., Min, K. N., Kong, G., Hur, G. M., et al. (2014). $\beta$-Lapachone alleviates alcoholic fatty liver disease in rats. Cell. Signal. 26, 295-305. doi: 10.1016/j.cellsig.2013.11.020

Syn, W. K., Jung, Y., Omenetti, A., Abdelmalek, M., Guy, C. D., Yang, L., et al. (2009). Hedgehog-mediated epithelial-to-mesenchymal transition and fibrogenic repair in nonalcoholic fatty liver disease. Gastroenterology 137, 1478.e8-1488.e8. doi: 10.1053/j.gastro.2009.06.051

Szondy, Z., Sarang, Z., Molnar, P., Nemeth, T., Piacentini, M., Mastroberardino, P. G., et al. (2003). Transglutaminase 2-/- mice reveal a phagocytosis-associated crosstalk between macrophages and apoptotic cells. Proc. Natl. Acad. Sci. U.S.A. 100, 7812-7817. doi: 10.1073/pnas.0832466100

Tang, Y., Bian, Z., Zhao, L., Liu, Y., Liang, S., Wang, Q., et al. (2011). Interleukin-17 exacerbates hepatic steatosis and inflammation in non-alcoholic fatty liver disease. Clin. Exp. Immunol. 166, 281-290. doi: 10.1111/j.13652249.2011.04471.x

Taura, K., Miura, K., Iwaisako, K., Osterreicher, C. H., Kodama, Y., PenzOsterreicher, M., et al. (2010). Hepatocytes do not undergo epithelialmesenchymal transition in liver fibrosis in mice. Hepatology 51, 1027-1036. doi: 10.1002/hep. 23368

Tayel, A., Abd El Galil, K. H., Ebrahim, M. A., Ibrahim, A. S., El-Gayar, A. M., and Al-Gayyar, M. M. (2014). Suramin inhibits hepatic tissue damage in hepatocellular carcinoma through deactivation of heparanase enzyme. Eur. J. Pharmacol. 728, 151-160. doi: 10.1016/j.ejphar.2014.02.001

Thapaliya, S., Wree, A., Povero, D., Inzaugarat, M. E., Berk, M., Dixon, L. et al. (2014). Caspase 3 inactivation protects against hepatic cell death and ameliorates fibrogenesis in a diet-induced NASH model. Dig. Dis. Sci. 59, 1197-1206. doi: 10.1007/s10620-014-3167-6

Trachtman, H., Fervenza, F. C., Gipson, D. S., Heering, P., Jayne, D. R., Peters, H., et al. (2011). A phase 1, single-dose study of fresolimumab, an anti-TGF$\beta$ antibody, in treatment-resistant primary focal segmental glomerulosclerosis. Kidney Int. 79, 1236-1243. doi: 10.1038/ki.2011.33

Tugues, S., Fernandez-Varo, G., Muñoz-Luque, J., Ros, J., Arroyo, V., Rodés, J., et al. (2007). Antiangiogenic treatment with sunitinib ameliorates inflammatory infiltrate, fibrosis, and portal pressure in cirrhotic rats. Hepatology 46, 1919-1926. doi: 10.1002/hep.21921

Wang, B., Dolinski, B. M., Kikuchi, N., Leone, D. R., Peters, M. G., Weinreb, P. H., et al. (2007). Role of alphavbeta6 integrin in acute biliary fibrosis. Hepatology 46, 1404-1412. doi: 10.1002/hep.21849 
Wang, L., Chen, S., and Xu, K. (2011). IL-17 expression is correlated with hepatitis B-related liver diseases and fibrosis. Int. J. Mol. Med. 27, 385-392. doi: 10.3892/ijmm.2011.594

Wang, Y., Chen, X., Cao, W., and Shi, Y. (2014). Plasticity of mesenchymal stem cells in immunomodulation: pathological and therapeutic implications. Nat. Immunol. 15, 1009-1016. doi: 10.1038/ni.3002

Wells, R. G. (2014). The portal fibroblast: not just a poor man's stellate cell. Gastroenterology 147, 41-47. doi: 10.1053/j.gastro.2014.05.001

Witek, R. P., Stone, W. C., Karaca, F. G., Syn, W. K., Pereira, T. A., Agboola, K. M., et al. (2009). Pan-caspase inhibitor VX-166 reduces fibrosis in an animal model of nonalcoholic steatohepatitis. Hepatology 50, 1421-1430. doi: 10.1002/hep. 23167

Ye, J. S., Su, X. S., Stoltz, J. F., de Isla, N., and Zhang, L. (2015). Signalling pathways involved in the process of mesenchymal stem cells differentiating into hepatocytes. Cell Prolif. 48, 157-165. doi: 10.1111/cpr.12165

Yoshiji, H., Noguchi, R., Kuriyama, S., Ikenaka, Y., Yoshii, J., Yanase, K., et al. (2005). Imatinib mesylate (STI-571) attenuates liver fibrosis development in rats. Am. J. Physiol. Gastrointest. Liver Physiol. 288, G907-G913. doi: 10.1152/ajpgi.00420.2004

Zeisberg, M., Yang, C., Martino, M., Duncan, M. B., Rieder, F., Tanjore, H., et al. (2007). Fibroblasts derive from hepatocytes in liver fibrosis via epithelial to mesenchymal transition. J. Biol. Chem. 282, 23337-23347. doi: 10.1074/jbc.M700194200

Zhang, X., Tan, Z., Wang, Y., Tang, J., Jiang, R., Hou, J., et al. (2015). PTPROassociated hepatic stellate cell activation plays a critical role in liver fibrosis Cell. Physiol. Biochem. 35, 885-898. doi: 10.1159/000369746

Zhang, Y., Chen, L., Gao, W., Hou, X., Gu, Y., Gui, L., et al. (2012). IL-17 neutralization significantly ameliorates hepatic granulomatous inflammation and liver damage in Schistosoma japonicum infected mice. Eur. J. Immunol. 42, 1523-1535. doi: 10.1002/eji.201141933

Conflict of Interest Statement: The authors declare that the research was conducted in the absence of any commercial or financial relationships that could be construed as a potential conflict of interest.

Copyright (C) 2016 Wang, Koyama, Liu, Xu, Ma, Liang, Kim, Brenner and Kisseleva. This is an open-access article distributed under the terms of the Creative Commons Attribution License (CC BY). The use, distribution or reproduction in other forums is permitted, provided the original author(s) or licensor are credited and that the original publication in this journal is cited, in accordance with accepted academic practice. No use, distribution or reproduction is permitted which does not comply with these terms. 